Kamil Niewiński

Uniwersytet w Białymstoku e-mail: kamilnwsk18@gmail.com telefon: 507681500

DOI: $10.15290 /$ mhi.2017.16.02.08

\title{
Ruch związkowy w prokuraturze PRL w latach 1980-81
}

\begin{abstract}
SUMMARY
Labour union movement in the Prosecutor's Office of the Polish People's Republic in the years $1980-81$
\end{abstract}

The Prosecutor's Office of the Polish People's Republic was a highly politicised organ. Most prosecutors have linked their careers with the ruling Polish United Workers' Party. However, the momentous events of August 1980, exerted an influence on this milieu. The social renewal movement under the banner of "Solidarity" did not find many sympathisers. Prosecutors related to the political system, however, created at the turn of 1980-1981, a new Labour Union of Prosecutor's Office Workers. Through this organizsation, they conducted a dialogue with the authorities. Prosecutors expected changes that would strengthen their independence, role and position in state structures.

Key words: Prosecutor's Office, prosecutor, "Solidarity", labour union

Słowa kluczowe: prokuratura, prokurator, „Solidarność”, związek zawodowy

\section{Wpływ wydarzeń sierpnia 1980 roku na środowisko prokuratorskie}

W każdym państwie o charakterze totalitarnym niezwykle istotne dla utrzymania władzy jest zachowanie karności wojska oraz bezwzględnej dyspozycyjności organów bezpieczeństwa wewnętrznego, porządku publicznego i ścigania. Dlatego w okresie Polskiej Rzeczpospolitej Ludowej (dalej: PRL), obok Służb Bezpieczeństwa i Milicji Obywatelskiej (dalej: MO), w wysokim stopniu upolitycznione było środowisko prokuratorskie. W latach siedemdziesiątych do rządzącej w kraju Polskiej Zjednoczonej Partii Robotniczej (dalej: PZPR) należało ponad 2000 prokuratorów, tj. ok. 70\% ogółu zatrudnionych, 
przy czym prokuratorzy bezpartyjni pozostawali jedynie na najniższym szczeblu prokuratur rejonowych ${ }^{1}$. Większość prokuratorów związało więc swoją karierę zawodową z rządzącą PZPR, stało „twardo na gruncie pryncypiów ustroju socjalistycznego", jak określali tę postawę partyjni ideolodzy. Trwałość ustroju PRL i stabilność władzy PZPR leżała w interesie większości prokuratorów, głównie tych z wyższego i najwyższego szczebla prokuratorskiej hierarchii.

Ze względu na wysoki stopień upartyjnienia środowisko było silnie zintegrowane $\mathrm{w}$ ramach podstawowych organizacji partyjnych PZPR oraz rad zakładowych branżowego pionu prokuratorskiego w Związku Zawodowym Pracowników Państwowych i Społecznych, zwanym potocznie związkiem „Państwowców" (dalej: ZZPPiS), działającym przy poszczególnych jednostkach prokuratury. Był to koncesjonowany związek zawodowy. Zrzeszał on ogół pracowników państwowych. Oprócz prokuratorów i pracowników administracyjnych prokuratur, do ZZPPiS należała także większość sędziów i pracowników administracyjnych sądów, pracowników administracji rządowej i terenowej oraz jednostek gospodarki uspołecznionej. Była to ogromna organizacja, której władze były całkowicie zależne od PZPR. Z tych względów ZZPPiS była faktycznie niezdolna do obrony partykularnych interesów poszczególnych grup zawodowych. Związek ten był po prostu jedną z wielu funkcjonujących w PRL i odgórnie sterowanych organizacji, które miały na celu pozorowanie demokratyzmu państwa.

Znane powszechnie wydarzenia sierpnia 1980 r. - ogólnopolskie strajki, społeczne żądania demokratyzacji życia państwowego, z nadrzędnym postulatem wolności związkowej - wniosły dopiero powiew wolności. W tzw. porozumieniach sierpniowych, zawartych przez rząd ze strajkującymi robotnikami stoczni szczecińskiej i gdańskiej oraz górnikami z Jastrzębia, władze wyraziły zgodę na tworzenie niezależnych i samorządnych związków zawodowych ${ }^{2}$. Porozumienia dały początek wielkiemu ruchowi społecznemu pod sztandarem „Solidarności", otworzyły furtkę do prowadzenia z władzami PRL rzeczywistej, a nie odgórnie reżyserowanej dyskusji o stanie gospodarki, społeczeństwa i państwa ${ }^{3}$. Te rewolucyjne wydarzenia nie pozostały bez wpływu również w środowisku prokuratorskim.

\footnotetext{
R. Walczak, Polityka, sady, prokuratura, Warszawa 1990, s. 162.

2 W. Giełżyński, L. Stefański, Gdańsk, sierpień 80, Warszawa 1981, s. 212; L. Biernacki, Kronika "Solidarności". 20 lat dzień za dniem..., Sopot 2000, s. 26.

3 Zob. J. Holzer, „Solidarność” 1980-1981. Geneza i historia, Paryż 1984, passim; A. Friszke, Rewolucja Solidarności 1980-1981, Kraków 2014, passim; A.L. Sowa, Wielka historia Polski, od drugiej do trzeciej Rzeczypospolitej (1945-2001), t. 10, Kraków 2001, s. 281-297; A.L. Sowa, Historia polityczna Polski 1944-1991, Kraków 2011, s. 441-505; A. Paczkowski, Pół wieku dziejów Polski, Warszawa 2007, s. $317-343$.
} 
W pierwszych miesiącach posierpniowych wydarzeń, między wrześniem a listopadem 1980 r., w poszczególnych prokuraturach były masowo organizowane zebrania rad zakładowych ZZPPiS oraz POP PZPR. Prokuratorzy, korzystając ze wzorców społecznych, wystosowali szereg własnych postulatów do kierownictw poszczególnych prokuratur i do Prokuratury Generalnej.

Oczekiwania prokuratorów nie skupiały się wyłącznie wokół kwestii płacowych i socjalnych, choć tego typu żądania były wysuwane najczęściej (podwyżki płac, przyznanie prokuratorom licznych dodatkowych ulg, zabezpieczeń socjalnych i emerytalnych, zastopowanie procesu redukcji etatów, wprowadzenie sztywnych regulacji w zakresie czasu pracy). Środowisko formułowało także postulaty dotyczące funkcjonowania i zmian ustrojowych w prokuraturze. Do tej grupy możemy zaliczyć żądania:

- ustalenia jednolitego, jawnego i przejrzystego systemu wynagradzania i awansów w taki sposób, aby zlikwidowane zostały różnice $\mathrm{w}$ uposażeniach prokuratorów tych samych szczebli oraz wykluczona została samowola kierownictwa w kształtowaniu polityki kadrowej i płacowej5;

- dokonania zmian $\mathrm{w}$ systemie szkolenia prokuratorów i aplikantów prokuratorskich;

- odejścia od praktyki oceny pracy prokuratorów opartej na wskaźnikach statystycznych i nieadekwatne do charakteru funkcji prokuratora zasady współzawodnictwa pracy ${ }^{7}$;

4 Uchwały i wykazy postulatów opracowane na zebraniach rad zakładowych ZZPPiS i POP PZPR w prokuraturach poszczególnych województw zgromadzone są w Archiwum Akt Nowych w Warszawie (dalej: AAN), w zbiorze 842 Prokuratura Generalna PRL (dalej: PG), w teczce o sygn. 6/342, k. 222-388.

5 W ramach zebrań rad zakładowych ZZPPiS przy poszczególnych prokuraturach formułowano m.in. postulaty: podawania do wiadomości ogólnej wszystkich przyznawanych nagród i podwyżek płac, jednolitego uregulowania sposobu i terminów awansów, w szczególności wprowadzenia zasady przechodzenia do wyższych grup uposażeń z urzędu wraz z upływem określonego okresu, np. co 3-4 lata, określenia sztywnych zasad przyznawania przez Prokuratora Generalnego dodatku specjalnego, wprowadzenia obowiązku konsultowania decyzji w tym zakresie z radami zakładowymi ZZPPiS. Pojawiały się również koncepcje zastąpienia systemu nagród przez tzw. trzynastą pensję. Ibidem, k. 266, 268-271, 278, 281, 298, 317, 329, 332, 334, 338-339, 349, 358-359, 369-370, 378-380.

6 Postulowano powrót do systemu odbywania przez aplikantów praktyk $\mathrm{w}$ różnych działach prokuratury i sądu oraz $\mathrm{w}$ organach $\mathrm{MO}$ - pod patronatem odpowiedzialnego prokuratora, $\mathrm{z}$ okresowymi konsultacjami, kolokwiami oraz egzaminem prokuratorskim przed centralnie powołaną komisją. Usprawnieniu szkolenia aplikantów miało sprzyjać dodatkowo organizowanie przez Prokuraturę Generalną 6-tygodniowych kursów centralnych na koniec aplikacji. Prokuratorzy wskazywali przy tym, aby "uczyć bardziej wszechstronnie, a nie tylko na rzecz doraźnej praktyki”. Zestawienie wniosków i propozycji zgłoszonych na naradzie prokuratorów wojewódzkich i I Sekretarzy POP, odbytej w dniu 4 XI 1980 r. we Wrocławiu, ibidem, k. 383.

7 Prokuratorzy nazywali to „szkodliwą praktyką", która powodowała w rzeczywistości spadek jakości pracy prokuratury. Ocena przez pryzmat statystyki stanowiła „antybodziec do podnoszenia 
- odejścia od praktyki zbyt częstego zlecania prowadzenia postępowań przygotowawczych innym organom ${ }^{8}$ oraz wzmocnienie nadzoru nad postępowaniami prowadzonymi przez $\mathrm{MO}^{9}$;

- reform strukturalnych, przez likwidację małych prokuratur wojewódzkich, bądź ich scalenie i utworzenie większych, silnych kadrowo jednostek dla jednego lub większej liczby województw w postaci prokuratur okręgowych ${ }^{10}$;

- reformy systemu hierarchicznego podporządkowania i wprowadzenia większej swobody działalności prokuratorów.

Poszczególnym postulatom $\mathrm{w}$ zakresie ostatniego z zagadnień warto poświęcić więcej uwagi. Opolscy prokuratorzy podnosili bowiem bardzo istotny problem bezwzględności stosowania $\mathrm{w}$ praktyce funkcjonowania prokuratury zasady hierarchicznego podporządkowania prokuratora niższego szczebla prokuratorowi szczebla wyższego. Prokuratorzy musieli wykonywać polecenia przełożonych. Nie mogli poddawać w wątpliwość ich słuszności, nawet w przypadkach, gdy - ich zdaniem - były one sprzeczne z prawem. Opolscy prokuratorzy domagali się z tego względu zmian w uchwale Rady Państwa z dnia 22 grudnia $1967 \mathrm{r}$. w sprawie statutu powszechnych jednostek organizacyjnych Prokuratury PRL (M.P. z 1977 r. Nr 14, poz. 81 t.j.). Żądali wprowadzenia przepisu nie tylko uprawniającego, ale zobowiązującego każdego prokuratora do pisemnego zawiadomienia o fakcie otrzymania polecenia naruszającego

jakości na rzecz ilości". Lista postulatów zgłoszonych przez pracowników prokuratur województwa opolskiego na otwartym zebraniu Zakładowej Organizacji Zwiazkowej ZZPPiS, odbytym w dniu 25 IX 1980 r., ibidem, k. 331. Mechanizmy oceny statystycznej skłaniały prokuratorów do fałszowania statystyki obrazującej wykrywalność przestępstw i szybkość postępowania karnego. Wnioski zgłoszone podczas zebrania Oddziałowej Organizacji Partyjnej PZPR przy Departamencie Postępowania Karnego i Ułaskawień $w$ dniach 6 i 11 XI 1980 r., ibidem, k. 222. Prokuratorzy domagali się przyjęcia systemu opiniowania polegającego na stopniowaniu i wprowadzeniu ocen opisowych.

8 Prokuratorzy lubelscy apelowali o rozszerzenie praktyki osobistego prowadzenia śledztw przez prokuratorów. Lista wniosków i postulatów zgłoszonych do dnia 28 XI 1980 r. przez pracowników prokuratur województwa lubelskiego do Komisji powołanej zarządzeniem Prokuratora Wojewódzkiego w Lublinie $\mathrm{Nr}$ 6/80/Z, ibidem, k. 316.

9 Wnioski zgłoszone podczas zebrania Oddziałowej Organizacji Partyjnej PZPR przy Departamencie Postępowania Karnego i Utaskawień w dniach 6 i 11 XI 1980 r., ibidem, k. 224.

10 Uchwała podjęta na specjalnym posiedzeniu komisji Rady Zakładowej ZZPPiS przy Prokuraturze Wojewódzkiej w Bydgoszczy w dniu 23 X 1980 r., ibidem, k. 236; Lista wniosków i postulatów zgłoszonych do dnia 28 XI 1980 r. przez pracowników prokuratur województwa lubelskiego..., k. 316. Z krytyką prokuratorów spotkał się destrukcyjny wpływ na jakość funkcjonowania jednostek prokuratury szczebla wojewódzkiego reformy podziału administracyjnego kraju dokonanej w połowie lat siedemdziesiątych. Rozpoczął się wówczas proces tworzenia jednostek prokuratury dla wszystkich, utworzonych wówczas 49 województw. Skutkowało to powstaniem małych i słabych kadrowo prokuratur wojewódzkich. Podobny problem dotyczył sądownictwa powszechnego. Rozdrobnienie na szczeblu sądów wojewódzkich w 1981 r. spotkało się z krytyką sędziów i Ministerstwa Sprawiedliwości. Zob. K. Niewiński, PZPR a sadownictwo w latach 1980-1985. Próby powstrzymania „solidarnościowej" rewolucji, Oświęcim 2016, s. 140-146. 
prawo bezpośredniego przełożonego w stosunku do prokuratora, który wydał polecenie ${ }^{11}$.

Opolscy prokuratorzy zwracali ponadto uwagę nie tylko na problem bezwzględnej podległości służbowej w ustawowych ramach funkcjonowania prokuratury. Odważnie mówili również o pozaprawnej podległości prokuratorów wytycznym instancji partyjnych, a także "poleceniom, sugestiom, życzeniom itp. poszczególnych funkcjonariuszy aparatu partyjnego". Wskazywali na trawiący prokuraturę problem "fasadowości, wymuszonej ceremonii i czołobitności w stosunku do osób wysoko ustawionych w społecznej i urzędowej hierarchii". Postulowali oni uniezależnienie prokuratorów od potrzeb i partykularnych interesów prominentów PZPR. Wykluczona powinna była zostać zdaniem opolskich prokuratorów - „możliwość żądania przez nich od prokuratorów tłumaczenia się z poszczególnych indywidualnych decyzji oraz udzielania prokuratorowi "wytycznych" w tych sprawach". Godzili się oni jednak na podległość „,W czynnościach zawodowych (...) uchwałom statutowych organów partii"12.

Z podnoszonymi problemami bezwzględnej podległości prokuratorów poleceniom służbowym, a także partyjnym, łączyła się sprawa możliwości swobodnego pozbawiania prokuratorów stanowisk z przyczyn politycznych, tzw. „braku rękojmi należytego wykonywania obowiązków”, o czym stanowił art. 13 ust. 1 pkt 1 ustawy z dnia 14 kwietnia 1967 r. o Prokuraturze PRL (Dz. U. Nr 13, poz. 55 ze zm.). Brak możliwości odwołania się prokuratora od decyzji władz o zwolnieniu go ze służby na podstawie przepisu o „braku rękojmi" krytycznie oceniali prokuratorzy bydgoscy i warszawscy - z prokuratur Ochota i Południe. Przepis ten mógł być bowiem mechanizmem wymuszania na prokuratorach postępowania zgodnego nawet ze sprzecznymi z prawem wytycznymi kierownictwa prokuratury, centralnych i terenowych instancji partyjnych i poszczególnych działaczy PZPR. Prokuratorzy bydgoscy i warszawscy domagali się ograniczenia swobody podejmowania decyzji o zwolnieniu przez zobowiązanie Prokuratora Generalnego do każdorazowego, uprzedniego zasięgania opinii właściwej związkowej rady zakładowej. Prokuratorzy domagali się ponadto, aby zwolnionemu z przyczyn „braku rękojmi” przysługiwało odwołanie do okręgowego sądu pracy i ubezpieczeń społecznych ${ }^{13}$.

Posierpniowe postulaty prokuratorskie świadczyły o ożywczym wpływie ruchu "solidarnościowej” odnowy na to środowisko. Prokurator Generalny PRL Lucjan Czubiński wskazywał, iż jesienią 1980 r. pod przemożnym

12 Ibidem, k. 329 i 331.

13 Uchwała podjęta na specjalnym posiedzeniu komisji Rady Zakładowej ZZPPiS przy Prokuraturze Wojewódzkiej w Bydgoszczy w dniu 23 X 1980 r., ibidem, k. 237; Postulaty zgłoszone przez grupy zwiazkowe w prokuraturach rejonowych oraz wydziałach Prokuratury Wojewódzkiej w Warszawie, ibidem, k. 372. 
wpływem rewolucyjnych wydarzeń w kraju znajdowała się szczególnie młoda kadra ${ }^{14}$. Ta część prokuratorów oczekiwała głębokich przeobrażeń $\mathrm{w}$ zakresie ich funkcjonowania wewnątrz organu. Wydarzenia posierpniowe $\mathrm{w}$ kraju pokazały zaś, iż siłę rozwojowi i możliwościom osiągnięcia realizacji zgłaszanych postulatów środowiskowych nadać mogła wyłącznie solidarność poszczególnych grup zawodowych i samoorganizacja środowiska $\mathrm{w}$ ramach struktur związkowych. Dlatego jesienią 1980 r. ważnym tematem dyskusji w prokuraturach całego kraju stała się również odnowa w ruchu związkowym.

\section{Dyskusja nad przyszłością ruchu związkowego w prokuraturze}

Wydarzenia sierpnia 1980 r. pozwoliły nie tylko mówić głośno o problemach ustroju socjalistycznego, ale również otworzyły drzwi do tworzenia przez wszystkie grupy zawodowe niezależnych od władz i samorządnych związków. Jesienią 1980 r. coraz częściej w środowisku prokuratorskim mówiło się o potrzebie skorzystania z tego prawa, zerwania z podległym władzy ZZPPiS i utworzenia nowych struktur związkowych, które będą zdolne do przeforsowywania wysuwanych postulatów.

24 października 1980 r., na zorganizowanym przez Zarząd Główny ZZPPiS zebraniu, przedstawiciele rad zakładowych przy prokuraturach całego kraju, niemal jednomyślnie, opowiedzieli się za wystąpieniem ze struktur ZZPPiS. Prokuratorzy nie mogli bowiem $w$ ramach tego związku działać samodzielnie. Jako jeden z licznych pionów branżowych, uzależnieni byli od decyzji władz centralnych, przez co nie widzieli oni realnej możliwości skutecznego dochodzenia realizacji wysuwanych postulatów w ramach tego związku.

Zarząd Główny ZZPPiS podjął kroki w kierunku zachęcenia prokuratorów do pozostania w strukturach związku „Państwowców”. Opracowane zostały założenia powołania Środowiskowej Rady Autonomicznej Pracowników Prokuratury PRL w ramach ZZPPiS, która miała reprezentować interesy prokuratorów. „Sądzono, że propozycja utworzenia Rady Środowiskowej zaspokoi postulaty tych kolektywów, które domagały się odrębności związkowej i zapobiegnie tendencjom odśrodkowym występującym silnie wśród młodszych pracowników w niektórych prokuraturach" ${ }^{\prime 15}$. Jednak ostatecznie do marginalizacji roli tego związku w środowisku prokuratorskim przyczyniło się kierownictwo Prokuratury Generalnej. Porzucenie przez większość prokuratorów szeregów

14 Informacja z dnia 23 XII 1980 r. w sprawie związów zawodowych w Prokuraturze PRL, AAN, 1354 KC PZPR, sygn. LI/39 [brak numeracji porządkowej kart w teczce].

15 Ibidem [brak numeracji porządkowej kart w teczce]. 


\section{związku „Państwowców” było wynikiem niezadowolenia ze stopnia realizacji zgłoszonych po sierpniu postulatów ${ }^{16}$. Sytuacja ta pogłębiała w środowisku przekonanie, iż ZZPPiS, ,jako ogromna organizacja zrzeszająca pracowników najróżniejszych zawodów i środowisk, nie uwzględniał i nie mógł uwzględ-}

16 W dniu 21 X 1980 r. Prokurator Generalny powołał specjalną komisję ds. rozpatrywania zgłoszonych przez pracowników prokuratur wniosków i postulatów. W skład komisji weszli pracownicy Prokuratury Generalnej: Zygmunt Grabiec - wicedyrektor Departamentu Kadr, Szkolenia i Spraw Socjalnych, Edward Kempka - starszy inspektor, Roman Oleśniewicz - prokurator, Bogumił Surowski - dyrektor Departamentu Organizacyjnego (przewodniczący komisji), Lech Turski - wicedyrektor Departamentu Budżetowo-Administracyjnego oraz Teresa Twardowska - prokurator. Zarzadzenie Nr 5/80 Prokuratora Generalnego PRL z dnia 21 X 1980 r. w sprawie rozpatrywania $i$ załatwiania postulatów i wniosków załóg pracowniczych, AAN, 842 PG, sygn. 6/342, k. 211 oraz sygn. 6/81, k. 309. W dniu 8 XII 1980 r. przedstawione zostało przez Prokuraturę Generalną stanowisko komisji ds. rozpatrywania zgłoszonych przez pracowników prokuratur wniosków i postulatów, wraz z propozycjami realizacji części żądań, zaakceptowane przez Kolegium Prokuratury Generalnej. Kierownictwo prokuratury odniosło się pozytywnie do większości postulatów płacowych i socjalno-bytowych. Za słuszne uznano m.in. przyznanie prokuratorom tzw. trzynastej pensji, podwyżek płac, uzyskanie dodatkowych ulg socjalnych, czy większość postulatów w zakresie uprawnień emerytalnych. Przy każdym tego typu postulacie podkreślano jednak, iż ostateczna decyzja co do ich realizacji i wysokości zwiększenia środków na te cele należeć będzie do ministra pracy, płacy i spraw socjalnych. Prokuratura Generalna zgodziła się ponadto na zniesienie krytykowanego współzawodnictwa pracy oraz ograniczenie roli wskaźników statystycznych przy ocenie merytorycznej pracowników. Zapowiedziała uzależnienie przyznawania awansów i nagród „od faktycznego wyróżniania się w pracy zawodowej i społecznej, a nie od pełnionej funkcji kierowniczej”. Podkreślano jednak przy tym, iż „zasada ta nie może (...) wyłączać z nagradzania wyróżniających się w pracy zawodowej, politycznej i społecznej kadry kierowniczej”. Kierownictwo prokuratury widziało również potrzebę doskonalenia i wzmocnienia kadr. Zapowiedziało starania o zahamowanie redukcji etatów i przyznanie nowych w prokuraturach, w których istnieje największe obciążenie pracą oraz opracowanie nowych zasad centralnego szkolenia obecnych i przyszłych kadr prokuratorskich. Prokuratura Generalna nie widziała jednak możliwości zmniejszenia liczby prokuratur wojewódzkich bez jednoczesnej zmiany w podziale administracyjnym kraju. Uwagi i propozycje rozstrzygnięcia wniosków i postulatów pracowniczych zgłoszonych w prokuraturze PRL, AAN, 842 PG, sygn. 6/342, k. 1-29; Stanowisko Kierownictwa Prokuratury PRL w przedmiocie zgłaszanych przez pracowników postulatów i wniosków, ibidem, k. 169-185. Nie były to jednak konkretne zobowiązania, a ich faktyczna realizacja wciąż pozostawała w zawieszeniu. Na fakt ten zwracali uwage prokuratorzy gdańscy, którzy w uchwale z dnia 9 XII 1980 r. uznali przedstawiony przez Prokuraturę Generalną dokument ,jako zbyt ogólnikowy jeżeli chodzi o proponowane rozwiązania, niezawierający środków i zapowiedzi unormowań z określeniem terminu działań gwarantujących realizację zgłoszonych postulatów". Uchwała Rady Zakładowej Związku Zawodowego Pracowników przy prokuraturach województwa gdańskiego, ibidem, k. 149. Prokuratura Generalna nie ustosunkowała się do wielu zgłaszanych postulatów ustrojowych, np. kwestii ograniczenia dowolności w stosowaniu przepisu o obowiązku dawania przez prokuratora rękojmi należytego wykonywania obowiązków, bezwzględnej podległości poleceniom przełożonego, czy funkcjonalnej podległości prokuratorów instancjom i członkom centralnych i terenowych władz PZPR. Wywołało to eskalację postulatów w zakresie zmian w ustroju i usytuowaniu prokuratury w systemie organów władzy państwowej oraz wzmocnienia funkcjonalnej pozycji prokuratorów. Zob. Oświadczenie Rady Zakładowej, Komisji ds. Rozpatrywania Postulatów oraz kolektywu pracowniczego Prokuratury Wojewódzkiej w Lublinie, ibidem, k. 302-314; Protokót i lista postulatów zgłoszonych na posiedzeniu Prezydium Rady Zakładowej Pracowników prokuratury województwa katowickiego z dnia 15 XII 1980 r., ibidem, k. 252-263; Wnioski i postulaty zgłoszone przez członków POP w Prokuraturze Generalnej na zebraniach OOP, zaopiniowane na posiedzeniu egzekutywy POP w dniu 5 I 1981 r. do rozpatrzenia przez kierownictwo prokuratury PRL, AAN, 842 PG, sygn. 6/343, k. 66-72. 
niać specyfiki pracy w prokuraturze, a tym samym nie mógł zapewnić należytej obrony praw i interesów pracowników prokuratury"17. W efekcie nastąpił exodusu prokuratorów z ZZPPiS. W związku „Państwowców” w 1981 r. pozostało zaledwie 100 pracowników prokuratury, tj. ok. 1,5\% ogółu. Związek zachował wpływy jedynie $\mathrm{w}$ województwie szczecińskim i suwalskim. Poza tym zrzeszał on nieliczną grupę pracowników z kilku innych województw, a także z Prokuratury Generalnej ${ }^{18}$.

$\mathrm{W}$ tej sytuacji było jasne, iż w prokuraturze musiało dojść do odnowy $\mathrm{w}$ ruchu związkowym. $\mathrm{W}$ środowisku prokuratorskim początkowo przeważała koncepcja połączenia się z pokrewnymi branżami w jeden związek zawodowy pracowników wymiaru sprawiedliwości. Liczna rzesza prokuratorów chciała utworzenia wspólnego związku zawodowego z sędziami. Postulaty te były często wysuwane w posierpniowych uchwałach na wojewódzkich zebraniach pracowników prokuratur. Prezentowane $\mathrm{w}$ nich były różne koncepcje co do zasięgu branżowego związku oraz pozycji nowych struktur związkowych wobec PZPR. Przedstawiciele rad zakładowych prokuratur województw opolskiego i leszczyńskiego opowiadali się za reaktywacją Związku Zawodowego Sędziów i Prokuratorów w ramach Centralnej Rady Związków Zawodowych ${ }^{19}$. Prokuratorzy olsztyńscy, poznańscy, pilscy i toruńscy mówili jedynie o potrzebie utworzenia wspólnego z sędziami, autonomicznego związku zawodowego pracowników wymiaru sprawiedliwości i prokuratury ${ }^{20}$. Nie formułowali oni przy tym żadnych deklaracji o charakterze politycznym, w przeciwieństwie do przedstawicieli prokuratur województwa legnickiego, którzy proponowali „powołać samorządny i autonomiczny, uznający kierowniczą rolę partii (...), związek zrzeszający pracowników sądownictwa, prokuratury i notariatu"21. Prokuratorzy bydgoscy z kolei proponowali stworzenie ogromnych struktur Niezależnego Samorządnego Krajowego Związku Zawodowego Pracowników

17 Informacja $z$ dnia 23 XII 1980 r. w sprawie związków zawodowych w Prokuraturze PRL, AAN, 1354 KC PZPR, sygn. LI/39 [brak numeracji porządkowej kart w teczce].

18 Notatka Wydziału Administracyjnego KC PZPR o sytuacji zwiazkowej w Prokuraturze, ibidem, [brak numeracji porządkowej kart $\mathrm{w}$ teczce].

19 Lista postulatów zgłoszonych przez pracowników prokuratur województwa opolskiego na otwartym zebraniu Zakładowej Organizacji Zwiąkowej ZZPPiS, odbytym w dniu 25 IX 1980 r., AAN, 842 PG, sygn. 6/342, k. 328; Rejestr wniosków i postulatów, ibidem, k. 382.

20 Wyciag z protokołu odbytego w dniu 29 X 1980 r. zebrania Rady Zakładowej ZZPPiS przy prokuraturach woj. olsztyńskiego, ibidem, k. 325; Postulaty do Rady Zakładowej ZZPPiS przy Prokuraturze Wojewódzkiej w Pile z siedziba w Chodzieży, ibidem, k. 334; Komunikat Nr 5/80 z dnia 22 IX 1980 r. Rady Zaktadowej ZZPPiS przy Prokuraturze Wojewódzkiej w Poznaniu, ibidem, k. 339; Protokót z posiedzenia komisji do spraw rozpatrywania wniosków i postulatów zgłoszonych przez pracowników prokuratur województwa toruńskiego, powotanej zarządzeniem nr 11/80 Prokuratora Wojewódzkiego w Toruniu z dnia 4 XII 1980 r., ibidem, k. 363.

21 Wnioski pracowników prokuratur województwa legnickiego sformułowane na posiedzeniu komisji wnioskowej powołanej przez Radę Zakładowa ZZPPiS przy Prokuraturze Wojewódzkiej, ibidem, k. 301. 
Sądów i Prokuratur, w ramach którego dopuszczali możliwość zrzeszania się przedstawicieli wszystkich środowisk prawniczych, nie tylko sędziów i prokuratorów, ale też adwokatów, radców prawnych, notariuszy czy pracowników arbitrażu gospodarczego ${ }^{22}$.

Idea utworzenia wspólnego związku zawodowego sędziów i prokuratorów nie znalazła jednak poparcia $\mathrm{w}$ środowisku sędziowskim ${ }^{23}$. W sądach powstawały bowiem w tym czasie silne organizacje branżowe - NSZZ "Solidarność" Pracowników Wymiaru Sprawiedliwości (dalej: NSZZ „S" PWS) i „związek autonomiczny" NSZZ Pracowników Wymiaru Sprawiedliwości (dalej: NSZZ PWS) ${ }^{24}$.

Większość prokuratorów zaczęła więc - czerpiąc ze wzorców płynących od kolegów z sądownictwa - przychylać się do koncepcji utworzenia własnego, autonomicznego związku branżowego. Późną jesienią 1980 r. w środowisku pojawiały się również pierwsze sygnały poparcia dla społecznego ruchu „Solidarności". Pierwsi sekretarze POP PZPR w prokuraturach województwa wrocławskiego zwracali uwagę, iż tamtejsi prokuratorzy pozostawali „pod wrażeniem i odpowiednim wpływem sytuacji, jaka wytworzyła się w sądach oraz w innych środowiskach, które zadeklarowały przystąpienie do "Solidarności«"25.

Prokuratura Generalna była zaniepokojona rodzącym się poparciem w środowisku dla idei „Solidarności”. Z tego względu kierownictwo prokuratury poparło inicjatywę utworzenia związku autonomicznego. Prokuratura Generalna była gotowa podjąć wszelkie kroki celem zablokowania drogi do formowania się struktur NSZZ „Solidarność" w prokuraturach. Działania te okazały się jednak nie $\mathrm{w}$ pełni skuteczne. Podobnie jak $\mathrm{w}$ sądownictwie, $\mathrm{w}$ prokuraturze powstały dwa nowe związki zawodowe - autonomiczny Związek Zawodowy Pracowników Prokuratury PRL (dalej: ZZPP) oraz branżowa sekcja prokuratorska w ramach NSZZ „Solidarność”. W przeciwieństwie jednak do sądów, gdzie związki "autonomiczny” i "Solidarności” stały się dwiema równorzędnymi i znaczącymi siłami, w prokuraturze "Solidarność" zajmował równie marginalną pozycję, jak zdegradowane ZZPPiS.

22 Uchwała podjęta na specjalnym posiedzeniu komisji Rady Zakładowej ZZPPiS przy Prokuraturze Wojewódzkiej w Bydgoszczy w dniu 23 X 1980 r., ibidem, k. 236.

23 Mniej lub więcej solidarnie - relacja Piotra Ambroziewicza z przebiegu konferencji w Sądzie Wojewódzkim w Poznaniu w dniach 27-28 X 1980 r., „Prawo i Życie” (dalej: PiŻ) 1980, nr 46, s. 12. Zob. K. Niewiński, PZPR a sądownictwo..., dz. cyt., s. 49-66. Zob. też K. Niewiński, PZPR a zwiazki zawodowe w sądownictwie po sierpniu 1980 r., „Z Dziejów Prawa” 2015, t. 8 (16), s. 143-166. 


\section{Związek Zawodowy Pracowników Prokuratury PRL}

W dniu 25 listopada 1980 r. w Prokuraturze Generalnej zorganizowane zostało kolejne zebranie przedstawicieli istniejących jeszcze wówczas rad zakładowych ZZPPiS. Na zebraniu przedstawiono propozycję utworzenia związku autonomicznego. Koncepcja ta uzyskała poparcie 45 przedstawicieli spośród 48 reprezentowanych na zebraniu okręgów prokuratur wojewódzkich (nie byli obecni przedstawiciele woj. koszalińskiego). Powołany został komitet organizacyjny Związku Zawodowego Pracowników Prokuratury PRL. Wybrano również ośmioosobowe prezydium tego komitetu, które opracowało projekt statutu i rozesłało go celem konsultacji do wszystkich jednostek organizacyjnych prokuratury, wraz z wzorami deklaracji o przystąpieniu do nowego związku ${ }^{26}$.

Proces formowania się struktur związkowych i jego ostatecznej rejestracji trwał jednak bardzo długo. Związek Zawodowy Pracowników Prokuratury i jego statut ${ }^{27}$ zostały zarejestrowane w Sądzie Wojewódzkim w Warszawie po dwóch miesiącach od utworzenia komitetu założycielskiego, 26 stycznia $1981 \mathrm{r}^{28}$

Deklaracje przystąpienia do ZZPP podpisało blisko 6 tysięcy osób, tj. 90\% prokuratorów, pracowników administracji i obsługi prokuratury. Związek autonomiczny skonsolidował więc w swoich szeregach prawie całość środowiska i faktycznie wszedł w miejsce ZZPPiS. Nie stał się jednak organizacją zupełnie zależną od PZPR i kierownictwa prokuratury. Związkowcy zamierzali działać opierając się na zasadzie „nic o nas, bez nas”. Nie dążyli do rewolucyjnych zmian systemowych. Chcieli oni uzyskać realny wpływ na podejmowanie decyzji w kwestiach dotyczących spraw pracowniczych, ale również ustroju i funkcjonowania prokuratury.

Postawa ta znalazła odzwierciedlenie w uchwałach I Krajowego Zjazdu ZZPP, który odbył się w dwóch sesjach. Pierwsza miała miejsce w Warszawie $w$ dniach 5-6 marca, druga zaś w Czchowie, woj. tarnowskie, $w$ dniach 25-26 kwietnia 1981 r. Uczestniczyło w nim 138 delegatów, reprezentujących wszystkie województwa, oprócz suwalskiego, gdzie nie było wówczas organizacji związkowej ZZPP. Na pierwszej sesji Zjazdu obecni byli zaproszeni przedstawiciele "kierownictwa politycznego" z PZPR - jak to określił przewodniczący związku Stanisław Iwanicki ${ }^{29}$ - kierownictwa Prokuratury Gene-

26 Informacja z dnia 23 XII 1980 r. w sprawie związków zawodowych w Prokuraturze PRL, AAN, 1354 KC PZPR, sygn. LI/39 [brak numeracji porządkowej kart $\mathrm{w}$ teczce].

27 Statut Zwiazku Zawodowego Pracowników Prokuratury PRL, AAN, 842 PG, sygn. 6/310, k. 102-110; a także AAN, 842 PG, sygn. 6/27, k. 49-57.

28 Chcemy wspótdecydować o wszystkim - rozmowa z przedstawicielami RN ZZPP, „Gazeta Prawnicza” (dalej: GP) 1981, nr 10, s. 8.

29 Stanisław Iwanicki - wiceprokurator Prokuratury Wojewódzkiej w Radomiu, pełniący obowiązki przewodniczącego komitetu organizacyjnego, został wybrany na zjeździe przewodniczącym RN ZZPP. Stanowiska wiceprzewodniczących piastowali: prokurator Prokuratury Generalnej 
ralnej, a także liderzy sędziowskiego autonomicznego NSZZ PWS, pozostającego w stałym kontakcie ze związkiem prokuratorów. Druga sesja odbywała się wyłącznie $w$ gronie delegatów ZZPP.

Na czoło w uchwałach zjazdowych, oprócz spraw wewnątrzzwiązkowych $^{30}$, wysunięte zostały kwestie doskonalenia form prawnych działalności prokuratury, podniesienia społecznej rangi funkcji prokuratora oraz poprawy warunków życia i pracy pracowników powszechnych jednostek organizacyjnych prokuratury PRL ${ }^{31}$. Celem opracowania konkretnych propozycji rozwiązań i wystąpienia z nimi do kierownictwa prokuratury bądź odpowiednich organów władz, Zjazd powołał następujące komisje robocze:

- ds. kontaktów z organami władzy i administracji państwowej w składzie: Stanisław Miturski (Lublin), Zbigniew Rząsa (Warszawa), Janina Łotocka (Katowice), Jerzy Dutkowski (Olsztyn), Andrzej Kiedrowicz (Bydgoszcz) i Bogdan Machoń (Wałbrzych);

- ds. opracowania porozumienia z Prokuratorem Generalnym PRL, które to porozumienie miało obejmować wyłącznie postulaty płacowe i socjalno-bytowe ${ }^{32}$, w składzie: Stefan Jaworski (Słupsk), Adam Grzywacz (Wałbrzych), Aleksandra Lasota (Bydgoszcz), Alicja Niemirska (Radom), Stefan Lewiński (Kraków), Ryszard Rychlik (Warszawa);

Zdzisław Śliwiński oraz wiceprokurator Prokuratury Wojewódzkiej w Lublinie Stanisław Chodak, zaś sekretarza Rady Naczelnej wiceprokurator Prokuratury Wojewódzkiej w Warszawie Marian Hilarowicz. Zob. Notatka Wydziatu Administracyjnego KC PZPR o sytuacji zwiazkowej w Prokuraturze, AAN, 1354 KC PZPR, WA, sygn. LI/39 [brak numeracji porządkowej kart w teczce]. Nadmienić należy, iż w myśl przepisów statutu, zarejestrowanego przez SW w Warszawie w dniu 26 I 1981 r., a przyjętego bez zmian przez I Krajowy Zjazd, władzami centralnymi ZZPP były: Krajowy Zjazd Delegatów - najwyższy, uchwałodawczy organ związku, który miał zbierać się co 3 lata lub być zwoływany na sesje nadzwyczajne $z$ inicjatywy Rady Naczelnej bądź też na pisemny wniosek 1/5 pracowniczych organizacji związkowych albo 1/5 delegatów na poprzedni Zjazd Krajowy. Delegaci na Zjazd byli wybierani w proporcji - 1 na każdych 50 członków zakładowych organizacji związkowych. Rada Naczelna - wybierany co 3 lata przez Krajowy Zjazd organ wykonawczy i najwyższa władza związku w okresie między sesjami Krajowego Zjazdu. Miała ona realizować zadania ZZPP i kierować całokształtem jego działalności. Naczelna Komisja Rewizyjna - organ kontrolny. Zauważyć należy, iż Rada Naczelna miała zbierać się na posiedzenia planowo raz na kwartał. W okresach między posiedzeniami Rady większość jej zadań realizowało Prezydium RN, które miało z kolei zbierać się co najmniej raz w miesiącu. Faktycznie bieżące uprawnienia do reprezentowania i kierowania ZZPP posiadał Sekretariat Rady Naczelnej, w skład którego wchodzili przewodniczący i dwóch wiceprzewodniczących ZZPP, sekretarz i skarbnik. Identyczne struktury istniały na szczeblu organizacji zakładowych związku. Statut Związku Zawodowego Pracowników Prokuratury PRL, AAN, 842 PG, sygn. 6/310, k. 105-109.

30 Uchwała Nr 3 Krajowego Zjazdu ZZPP w sprawach wewnątrzzwiązkowych, wraz z aneksem, ibidem, k. $28-29$ i $95-96$.

31 Uchwała Nr 1 I Krajowego Zjazdu ZZPP w sprawie doskonalenia form prawnych działalności Prokuratury $P R L$ oraz podniesienia społecznej rangi funkcji prokuratora, wraz $\mathrm{z}$ aneksem, a także Uchwała $\mathrm{Nr} 2$ I Krajowego Zjazdu ZZPP w sprawie dalszej poprawy warunków życia i pracy pracowników powszechnych jednostek organizacyjnych Prokuratury PRL, AAN, 842 PG, sygn. 6/343, k. 4-10. Zob. też Uchwała I Krajowego Zjazdu Zwiazku Zawodowego Pracowników Prokuratury PRL, GP 1981, nr 9, s. 11. 
- ds. nowelizacji prawa w składzie: Teresa Majtas (Poznań), Stefan Lewiński (Kraków), Zofia Karbownik-Kiszka (Katowice), Kazimierz Mikołajczyk (Leszno), Bronisław Kośka (Łódź), Józef Piechota (Przemyśl), Ryszard Grupiński (Warszawa), Karol Mykietyn (Wrocław), Włodzimierz Meroń (Nowy Sącz) i Romuald Ochal (Radom) ${ }^{33}$.

Związek autonomiczny dążył do podjęcia współpracy z kierownictwem prokuratury. Chciał także wejść w kontakty z innymi organami władzy i administracji państwowej, celem uzyskania szerokiego wachlarza wpływów, wychodzącego poza sferę spraw pracowniczych.

Tak szeroko zakrojonej roli związku autonomicznego nie było przeciwne kierownictwo prokuratury. Stanowisko wobec miejsca i zadań ZZPP przedstawił na I Krajowym Zjeździe Delegatów związku Prokurator Generalny L. Czubiński. W swoim wystąpieniu zobowiązał się do stworzenia ZZPP odpowiednich warunków do „współuczestniczenia w kształtowaniu programów działania prokuratury i ich realizacji, rozwijania inicjatyw $\mathrm{w}$ zakresie organizacji pracy i jej wydajności, wyzwalania aktywnych postaw pracowniczych, prowadzenia działalności ideowo-wychowawczej i podnoszenia kwalifikacji, umacniania praworządności $\mathrm{w}$ sferze stosunków pracy, uczestniczenia $\mathrm{w}$ zaspokajaniu bytowych, socjalnych i kulturalnych potrzeb pracowników, emerytów i ich rodzin, wpływania na poprawę warunków pracy, wyrażania opinii i składania wniosków w sprawach odnoszących się do praw i obowiązków pracowniczych oraz funkcjonowania jednostek organizacyjnych". Zobligował on przy tym kierownictwa służbowe prokuratur wszystkich szczebli do zasięgania opinii związku przy podejmowaniu wszelkich decyzji dotykających spraw pracowniczych ${ }^{34}$. Prokurator Generalny wyraził również nadzieję na ułożenie partnerskich stosunków ze związkiem, które „na określonych odcinkach wykraczałyby poza sferę szeroko rozumianych spraw pracowniczych" 35 .

Na ogólnym tle poprawnie układającej się współpracy między związkowcami a kierownictwem prokuratury nie obyło się jednak i bez zgrzytów. Związkowcy aktywizowali się bowiem wobec bieżących wydarzeń społeczno-politycznych w kraju. Niepochlebnej ocenie związkowców poddane zostały działania władz po znanych wydarzeniach bydgoskich ${ }^{36}$. Rada Naczelna

33 Oprócz trzech wymienionych komisji, powołano również Komisję ds. rewindykacji majątku związku w składzie Zdzisław Śliwiński i Ryszard Kosiński (obydwaj Warszawa). Komunikat Nr 3 RN ZZPP z dnia 28 kwietnia 1981 r., ibidem, k. 23-24.

34 Przewodniczący RN ZZPP od początku $1981 \mathrm{r}$. brał udział, jako stały uczestnik, na posiedzeniach Kolegium Prokuratury Generalnej. Projekt poszerzenia kręgu osób zapraszanych do udziału w pracach Kolegium Prokuratury w roku 1981, AAN, 842 PG, sygn. 3/14, k. 34.

35 Wystapienie Prokuratora Generalnego PRL Lucjana Czubińskiego wygłoszone w dniu 5 III 1981 r. na I Zjeździe Delegatów ZZPP, AAN, 842 PG, sygn. 40/3, k. 55-56.

36 Chodziło o incydent pobicia przez służby mundurowe członków NSZZ „Solidarnośćc na sesji 
Związku Zawodowego Pracowników Prokuratury krytykowała wykorzystywanie sił porządkowych i prokuratorów „do niczym nieusprawiedliwionej ingerencji w funkcjonowanie organów przedstawicielskich" ${ }^{37}$. Ponadto władze związku wystąpiły, bezpośrednio do Prezesa Rady Ministrów gen. W. Jaruzelskiego, z postulatem włączenia przedstawicieli związków autonomicznych prokuratury i sądów, jako stron, zapoczątkowanych po wydarzeniach bydgoskich, rozmów między Komisją Rządową i NSZZ „Solidarność” w kwestiach szeroko pojętej praworządności. Zdaniem prokuratorów, w pracach komisji powinni byli uczestniczyć "ci, w interesie których prawo jest stanowione i stosowane, ci, którzy prawo to stanowią oraz ci, którzy prawo to w codziennej pracy stosują i stosować mają"38, a uczestnictwo przedstawicieli ZZPP było tym bardziej uzasadnione, iż przedmiotem rozważań komisji miały być m.in. sprawy związane $\mathrm{z}$ funkcjonowaniem prokuratury.

Z powodu tych wystąpień, 30 kwietnia $1981 \mathrm{r}$. zostało zorganizowane specjalne posiedzenie Kolegium Prokuratury Generalnej PRL, na którym wyrażono dezaprobatę wobec braku uprzedniego uzgodnienia przez władze związku z kierownictwem prokuratury wystąpienia i treści pism do Prezesa Rady Ministrów. Prokurator Generalny zwracał uwagę wezwanych na posiedzenie członków władz ZZPP, iż tego typu samowola związkowa była działaniem na szkodę prokuratury i prowadziła do poważnych rozdźwięków, które znacznie utrudniały prawidłowe funkcjonowanie całej prokuratury. Na Kolegium podkreślano potrzebę wypracowania dokumentu określającego trwałe zasady współpracy kierownictwa prokuratury z władzami ZZPP oraz wzajemne prawa i obowiązki stron, w szczególności w zakresie możliwości występowania i konsultacji spraw wychodzących ze związku na zewnątrz, poza jednostki prokuratury. W całej dyskusji członkowie Kolegium podkreślali potrzebę podjęcia ścisłej współpracy przez kierownictwo prokuratury i ZZPP, dla podniesienia rangi i przywrócenia nadwątlonego zaufania społecznego dla działalności prokuratury, „w sytuacji, gdy prokuratura jest bita i kopana z wielu stron, nie możemy walczyć między sobą", wskazywał L. Czubiński ${ }^{39}$.

2 czerwca 1981 r. Prokurator Generalny, w porozumieniu z RN ZZPP, wydał zalecenia dotyczące zasad współdziałania kierownictw służbowych prokuratury PRL ze związkiem autonomicznym. Zgodnie z tymi zasadami Prokurator Generalny zobowiązał się do konsultowania z RN ZZPP projektów aktów prawnych dotyczących regulacji płac i warunków pracy oraz istotnych

Wojewódzkiej Rady Narodowej w Bydgoszczy w dniu 19 marca 1981 r. K. Osiński, P. Rybarczyk, Kryzys bydgoski 1981. Przyczyny, przebieg, konsekwencje, t. I t. II, Bydgoszcz-Gdańsk-Warszawa 2013.

Pismo delegatów II sesji I Krajowego Zjazdu ZZPP, AAN, 842 PG, sygn. 6/343, k. 3.

Pismo z dnia 25 IV 1981 r. Rady Naczelnej ZZPP do Prezesa Rady Ministrów gen. Wojciecha Jaruzelskiego, AAN, 842 PG, sygn. 6/343, k. 1-2, a także sygn. 6/310, k. 25-26.

Zob. Protokół z posiedzenia Kolegium Prokuratury PRL w składzie rozszerzonym z dnia 30 kwietnia 1981 r., AAN, 842 PG, sygn. 3/19, k. 1-21. 
zagadnień ze sfery spraw pracowniczych. Ponadto kierownictwa służbowe prokuratur wszystkich szczebli miały służyć pomocą organizacjom związkowym w stworzeniu niezbędnych warunków dla realizacji ich statutowych celów i zadań oraz zasięgać opinii ogniw związkowych przed podjęciem decyzji w zakresie wszystkich spraw pracowniczych. Związek zobowiązany zaś był do ścisłego współdziałania z kierownictwem prokuratury w dążeniu do umacniania społecznego zaufania do organów prokuratury oraz dalszego usprawniania realizacji ich konstytucyjnych funkcji ochrony praworządności i porządku publicznego ${ }^{40}$.

Najistotniejszym osiągnięciem związku było zainicjowanie w Prokuraturze Generalnej prac legislacyjnych nad nowelizacją ustawy o Prokuraturze PRL ${ }^{41}$. W pracach tych uwzględnione miały zostać postulaty związkowe, zapewnione aktywne uczestnictwo przedstawicieli władz ZZPP, zaś sam projekt miał być poddany pod dyskusję środowiskową ${ }^{42}$.

Program reformy ustrojowej prokuratury został zaczerpnięty przez ZZPP ${ }^{43}$ z postulatów środowiskowych formułowanych jesienią 1980 r., rozszerzonych $\mathrm{w}$ tzw. dokumencie lubelskim ${ }^{44}$, które zostały uzupełnione $\mathrm{w}$ toku dyskusji zjazdowej i przyjęte pod koniec kwietnia 1981 r. przez I Krajowy Zjazd ZZPP, jako tezy do dyskusji z kierownictwem prokuratury nad zmianami jej ustroju ${ }^{45}$. Związek Zawodowy Pracowników Prokuratury domagał się przede wszystkim wzmocnienia pozycji ustrojowej prokuratury przez jej bezpośrednie podporządkowanie Sejmowi. Sejm, w zastępstwie Rady Państwa ${ }^{46}$, miał powoływać

40 Komunikat ze spotkania kierownictwa prokuratury PRL i Rady Naczelnej ZZPP w dniu 2 VI 1981 r., AAN, 842 PG, sygn. 40/3, k. 45-46 oraz sygn. 6/310, k. 122-124; zob. też Zasady wspótdziałania kierownictwa Prokuratury PRL z ZZPP - projekt, AAN, 842 PG, sygn. 6/27, k. 45-48.

41 W tym celu powołano zespół do opracowania tez w sprawie zmiany ustawy o Prokuraturze PRL, w skład którego weszli prokuratorzy: Jerzy Smoleński - doradca Prokuratora Generalnego, Henryk Pracki - dyrektor Departamentu III Prokuratury Generalnej, Bogumił Surowski - dyrektor Departamentu V Prokuratury Generalnej oraz przedstawiciele ZZPP: Stanisław Miturski - wiceprokurator Prokuratury Wojewódzkiej w Lublinie i Teresa Majtas - wiceprokurator Prokuratury Wojewódzkiej w Poznaniu. Komunikat ze spotkania kierownictwa prokuratury PRL..., k. 124 Ibidem, k. 124-125. Zob. Chcemy współdecydować o wszystkim..., s. 8.

Zob. Sformułowane 6 I 1981 r. postulaty prokuratorów województwa lubelskiego. Oświadczenie Rady Zakładowej, Komisji d/s Rozpatrywania Postulatów oraz kolektywu pracowniczego Prokuratury Wojewódzkiej w Lublinie, AAN, 842 PG, sygn. 6/342, k. 302-314. Podobne postulaty zgłaszali w tym czasie również członkowie POP PZPR w Prokuraturze Generalnej. Zob. Wnioski i postulaty zgłoszone przez członków POP w Prokuraturze Generalnej na zebraniach oddziałowych organizacji partyjnych, zaopiniowane na posiedzeniu Egzekutywy POP w dniu 5 stycznia 1981 r., AAN, 842 PG, sygn. 6/343, k. $67-72$.

45 Uchwała Nr 1 I Krajowego Zjazdu..., s. 4-7. Zob. też późniejsze Tezy do projektu ustawy o Prokuraturze $P R L$, AAN, 842 PG, sygn. 6/43, k. 37-39.

46 O pozycji prokuratury wobec organów władzy. Zob. S. Włodyka, Ustrój organów ochrony prawnej, Warszawa 1968, s. 202-210; J. Eksner, Prokurator rzecznikiem praworzadności, Warszawa 1974, s. 22-29; H. Zięba-Załucka, Instytucja prokuratury w Polsce, Warszawa 2003, s. 37-58. 
i odwoływać Prokuratora Generalnego oraz odbierać coroczne sprawozdania z działalności prokuratury PRL. Rada Państwa miała zachować uprawnienia do powoływania i odwoływania zastępców Prokuratora Generalnego oraz mianowania i zwalniania prokuratorów Prokuratury Generalnej i prokuratur wojewódzkich. Ponadto ZZPP dążyło do tego, aby Rada Państwa mianowała i zwalniała również prokuratorów rejonowych. W rękach Prokuratora Generalnego miało pozostawać prawo mianowania i zwalniania asesorów oraz przedstawiania kandydatów na stanowiska prokuratorskie wszystkich szczebli.

Postulaty ZZPP szły w kierunku wzmocnienia pozycji prokuratury również za pośrednictwem nowych kompetencji w zakresie jej działalności profilaktyczno-kontrolnej. Związkowcy domagali się przyznania Prokuratorowi Generalnemu PRL kompetencji do kontroli działalności prawotwórczej naczelnych organów administracji państwowej, w zakresie zgodności aktów normatywnych rządu z Konstytucją. W przypadku stwierdzonej sprzeczności proponowano, aby akty rządowe mogły być zaskarżane do Sądu Najwyższego nie istniał jeszcze wówczas Trybunał Konstytucyjny, nad którego powołaniem w 1981 r. dopiero dyskutowano. Oprócz tego kontrolą prokuratorską miały zostać objęte decyzje administracyjne. Związek Zawodowy Pracowników Prokuratury proponował również przyznanie Prokuratorowi Generalnemu prawa inicjatywy ustawodawczej, będące swoistym zwieńczeniem efektów pracy kontrolnej prokuratury nad całością działalności aparatu administracji państwowej.

Kolejnymi istotnymi reformatorskimi postulatami związkowymi było dążenie do wprowadzenia zasad nieusuwalności prokuratorów (zniesienie przepisu umożliwiającego odwołanie z przyczyn „braku rękojmi należytego wykonywania obowiązków") oraz niezależności zewnętrznej prokuratorów w ich działalności od innych organów władzy i administracji. W uchwale zjazdowej ZZPP nie było mowy o niezależności od PZPR. Jednak w wywiadzie dla tygodnika „Prawo i Życie” przedstawiciel ZZPP, lubelski prokurator Stanisław Miturski podkreślał, iż prokuratura powinna być w swej działalności niezależna również od organizacji politycznych, związkowych i społecznych, choć - jego zdaniem - nie oznaczało to wprost jej apolityczności, gdyż miała ona przede wszystkim chronić interesy państwa, opartego na określonym społeczno-politycznym

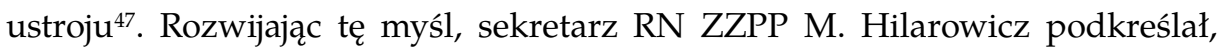
iż „funkcje aparatu partyjnego w żadnym wypadku nie mogą się sprowadzać do bezpośredniej ingerencji w działalność organów ścigania, zwłaszcza w jednostkowe rozstrzygnięcia" ${ }^{\prime 4}$. Niezbędna jego zdaniem była jednak wymiana informacji i współpraca prokuratury z partiami, związkami zawodowymi

47 Jednym z jego elementów była kierownicza rola PZPR w państwie, którą uznawało również ZZPP. Statut Zwiazku..., k. 102.

48 Potrzeba prawa - rozmowa red. J. Waniorka z przedstawicielami kierownictwa ZZPP, PiŻ 1981, nr 32, s. 4. 
i organizacjami społecznymi. Nie chodziło tu więc o zupełną niezależność prokuratury od zaleceń politycznych PZPR. Prokuratorzy - czego dali również wyraz $\mathrm{w}$ postulatach formułowanych jesienią $1980 \mathrm{r}$. - oczekiwali ukrócenia procederu wpływania na ich działalność przez prominentów partyjnych lub lokalnych grup interesów ${ }^{49}$.

Związek Zawodowy Pracowników Prokuratury oczekiwał również reform $\mathrm{w}$ funkcjonowaniu prokuratorów wewnątrz organu. Związkowcy domagali się wprowadzenia obowiązku przejęcia odpowiedzialności za podejmowane decyzje przez prokuratorów wyższego szczebla nad prokuratorami prowadzącymi postępowania. Dotychczas polecenia przełożonych mogły być ustne, a pod dokumentami obowiązkowo podpisywać się miał wyłącznie prokurator, któremu polecenie wydano, nawet wówczas, gdy z poleceniem się nie zgadzał. ZZPP proponowało wprowadzenie obowiązkowego podpisywania decyzji przez przełożonych ingerujących w jej treść.

Postawa władz związku autonomicznego w prokuraturze oraz dążenia reformatorskie ukazują, iż ZZPP stał na gruncie pryncypiów ustroju socjalistycznego i naczelnej zasady kierowniczej roli partii. Symboliczne było nie zawarcie przez prokuratorów w nazwie związku zwrotów "niezależny" i "samorządny". Trudno było bowiem mówić o tych przymiotach w stosunku do organizacji związkowej prokuratury, gdzie prokuratorzy usytuowani byli $\mathrm{w}$ ramach systemu hierarchicznego podporządkowania i która zrzeszała w ogromnej większości pracowników będących zarazem członkami PZPR. Niemniej jednak, czerpiąc z uprawnień uzyskanych na mocy porozumień sierpniowych i wzorców kolegów z sądownictwa, prokuratorzy zrzeszeni w ZZPP chcieli uzyskać rzeczywisty wpływ na sprawy własne środowiska, na kształtowanie ustroju prokuratury, wzmocnienie jej roli i zwiększenie prestiżu zawodu prokuratora.

\section{NSZZ „Solidarnośćc" w prokuraturze}

Formowanie się ruchu związkowego w prokuraturze PRL uwidoczniło skuteczność polityki kadrowej PZPR i wysoki poziom zdyscyplinowania służbowego i politycznego prokuratorów. Jednak pomimo wydanego przez Prokuratora Generalnego L. Czubińskiego zakazu przynależności prokuratorów

49 Warto w tym kontekście przytoczyć krótką wymianę zdań między prokuratorem S. Miturskim a redaktorem J. Waniorkiem zarzucającym prokuraturze bezczynność wobec znanych przypadków nieprawidłowości funkcjonowania władz, prowadzących do złego stanu gospodarki państwowej w drugiej połowie lat siedemdziesiatych. „S. Miturski - Dobrze. Załóżmy, że jest pan prokuratorem wojewódzkim i bez uzgodnienia wszczyna pan postępowanie np. przeciw wojewodzie, który jest członkiem egzekutywy KW [PZPR]... J. Waniorek: I co? S. Miturski: - I przestaje pan być prokuratorem wojewódzkim", ibidem, s. 5. 
do NSZZ „Solidarność” 50 i podjęcia licznych działań, które zmierzały do zachowania jednolitości ruchu związkowego, przede wszystkim inicjatywy skupienia prokuratorów $\mathrm{w}$ ramach związku autonomicznego, $\mathrm{w}$ prokuraturze powstały niewielkie przyczółki „Solidarności”.

Powstawaniu tego ruchu $\mathrm{w}$ prokuraturze sprzyjała opieszałość przy rejestracji autonomicznego ZZPP. W tym czasie zawiązały się $\mathrm{w}$ prokuraturze pierwsze ogniwa związkowe NSZZ „Solidarność”. Kierownictwu prokuratury nie udało się więc zupełnie zapobiec przeniknięciu idei „Solidarności” do środowiska.

W połowie grudnia 1980 r. zarejestrowane zostało Koło NSZZ „Solidarność" przy Prokuraturze Wojewódzkiej w Krakowie, które skupiało łącznie 22 osoby, w większości członków PZPR, spośród pracowników prokuratorskich, administracyjnych i obsługi z krakowskich prokuratur rejonowych oraz wyłącznie pracowników zatrudnionych na stanowiskach innych niż prokuratorskie w prokuraturze wojewódzkiej. W dniu 17 grudnia 1980 r. Koło NSZZ "Solidarność" powstało w Instytucie Problematyki Przestępczości w Warszawie. Liczyło ono 16 członków, a trzech $\mathrm{z}$ nich posiadało legitymację partyjną PZPR ${ }^{51}$.

Związek Zawodowy „Solidarność” Pracowników Prokuratury zrzeszał w sumie ok. 100-150 pracowników, z czego mniej więcej połowę stanowili prokuratorzy. Posiadał on reprezentację jedynie w prokuraturach rejonowych w Szczecinie, Olsztynie, Gdańsku, Bydgoszczy i Krakowie ${ }^{52}$, gdzie jego pozycja była najsilniejsza oraz w warszawskim Instytucie Problematyki Przestępczości.

Mimo znikomego zainteresowania w środowisku prokuratorskim koncepcją przyłączania się do ruchu społecznego „Solidarności”, 7 lutego 1981 r. powołano centralne struktury związkowe, w postaci Krajowej Komisji Koordynacyjnej NSZZ „Solidarność” Pracowników Prokuratury PRL. Inicjatywa scentralizowania kół $\mathrm{w}$ ogólnopolskie struktury wypłynęła na zorganizowanym przez sądową "Solidarność” I Ogólnopolskim Forum Pracowników Wymiaru Sprawiedliwości w Krakowie ${ }^{53}$. Na konferencji powołano Centrum Obywatelskich Inicjatyw Ustawodawczych (dalej: COIU) ${ }^{54}$. Narodziła się na niej również

50 Informacja $z$ dnia 23 XII 1980 r. w sprawie związków zawodowych w Prokuraturze PRL, AAN, 1354 KC PZPR, sygn. LI/39 [brak numeracji porządkowej kart w teczce].

51 Notatka Wydziału Administracyjnego KC PZPR w sprawie związków zawodowych w prokuraturze PRL, ibidem [brak numeracji porządkowej kart w teczce].

52 Notatka Wydziału Administracyjnego KC PZPR o sytuacji zwiazkowej w Prokuraturze, ibidem [brak numeracji porządkowej kart $\mathrm{w}$ teczce].

53 Obywatelskie Inicjatywy Ustawodawcze Solidarności 1980-1990, oprac. K. Barczyk, S. Grodziski, S. Grzybowski, Warszawa 2001, s. 25-30.

54 Była to nieformalna komórka powołana przy NSZZ „Solidarność” Pracowników Wymiaru Sprawiedliwości, w ramach której najwybitniejsi prawnicy z różnych środowisk, na bazie szerokiej społecznej dyskusji, podjęli trud opracowania szeregu projektów ustaw reformujących cały system socjalistycznego prawa. J. R. Sielezin, Koncepcje i spory programowe opozycji politycznej w Polsce 
koncepcja opracowania, $w$ ramach prac COIU, projektu nowelizacji ustawy o prokuraturze PRL. Zadanie to spoczęło na barkach zespołu pod przewodnictwem krakowskich prokuratorów, inicjatorów powołania „Solidarności” w prokuraturze, Andrzeja Herzoga i Krzysztofa Bachmińskiego ${ }^{55}$.

Krajowa Komisja Koordynacyjna NSZZ „Solidarność” Pracowników Prokuratury PRL przedstawiła projekt nowelizacji ustawy o Prokuraturze PRL ${ }^{56}$ na II Ogólnopolskim Forum Prawników w Krakowie 13 czerwca 1981 r. Proponowane w nim rozwiązania nie odbiegały znacząco od postulatów całego środowiska prokuratorskiego, zrzeszonego głównie w ZZPP. Prokuratorzy sympatyzujący z "Solidarnością" domagali się:

- podporządkowania prokuratury Sejmowi;

- zapewnienia niezależności zewnętrznej prokuratorów;

- wzmocnienia pozycji prokuratora wewnątrz organu (samodzielność w działaniu, podległość organizacyjna);

- wprowadzenia zasady nieusuwalności prokuratora poza drogą dyscyplinarną;

- rozszerzenia kompetencji prokuratury na sprawowanie kontroli zgodności aktów prawnych z Konstytucją (wniosek Prokuratora Generalnego do Sejmu o uchylenie aktu sprzecznego z Konstytucją);

- wzmocnienia nadzoru prokuratorskiego nad postępowaniami prowadzonymi przez $\mathrm{MO}$;

- powołania silnych kadrowo prokuratur okręgowych w miejsce prokuratur wojewódzkich.

Poza ostatnimi dwoma postulatami, większość propozycji reform nie znajdowała jednak poparcia w samej „Solidarności”. W społeczeństwie panowała bowiem negatywna opinia na temat funkcjonowania prokuratury PRL, głównie ze względu na jej wysoki stopień upolitycznienia. Dlatego przeważały poglądy, z jednej strony zaskakujące, mówiące o potrzebie podporządkowania prokuratury rządowi i włączeniu jej do pionu Ministerstwa Sprawiedliwości ${ }^{57}$, z drugiej strony, wielu zwolenników - co było wówczas zrozumiałe - znajdowała koncepcja ograniczenia roli prokuratury i przywrócenia instytucji niezależnych sędziów śledczych. Mieli oni przejąć do samodzielnego prowadzenia

w latach 1976-1982, Wrocław 2012, s. 262-263. Wypracowane projekty miały być przedmiotem obywatelskich inicjatyw ustawodawczych "Solidarności”, stanowiąc "alternatywny wariant w stosunku do projektów ustaw opracowywanych przez urzędników z poszczególnych ministerstw" Komunikat nr 1 Centrum Obywatelskich Inicjatyw Ustawodawczych NSZZ "Solidarność" z dnia 30 IV 1981 r., [w:] Obywatelskie inicjatywy..., s. 16. Zob. też J. Szczęsny, Obywatelskie Inicjatywy Ustawodawcze, GP 1981, nr 13-14, s. 10. A. Herzog, Z dziejów społecznego projektu ustawy o prokuraturze, [w:] Obywatelskie inicjatywy..., s. 543. Wstępny społeczny projekt nowelizacji ustawy z dnia 14 kwietnia 1967 r. o Prokuraturze PRL, [w:] ibidem, s. $107-112$.

57 A. Herzog, Z dziejów społecznego projektu..., s. 544. 
lub ściśle nadzorować postępowania przygotowawcze w sprawach o najcięższe przestępstwa $^{58}$.

\section{Zakończenie}

Wydarzenia posierpniowe w środowisku prokuratorskim ukazały, iż było ono ściśle powiązane $z$ systemem socjalistycznym i rządzącą PZPR. Okres społeczno-politycznych przemian lat 1980-81 nie pozostał jednak zupełnie bez echa w prokuraturze. Nastąpiła odnowa w ruchu związkowym, prokuratorzy domagali się przede większej wewnętrznej i zewnętrznej niezależności w działaniu. Środowisko liczyło na podniesienie rangi prokuratury i na drodze stopniowych przemian, odzyskanie mocno nadwątlonego zaufania społecznego.

Związek Zawodowy Pracowników Prokuratury stał się dominującą organizacją związkową i pomostem do przeforsowywania przez prokuratorów postulatów zmian w ustroju i funkcjonowaniu prokuratury PRL. Związkowcy ściśle współpracowali w tym zakresie z kierownictwem prokuratury. W Prokuraturze Generalnej zainicjowane zostały w połowie 1981 r. prace legislacyjne nad nowelizacją ustawy o Prokuraturze PRL. Pierwsze projekty opracowane pod koniec 1981 r. wychodziły naprzeciw oczekiwaniom środowiska. Jednak po wprowadzeniu stanu wojennego, zawieszeniu działalności związków zawodowych, ustabilizowaniu sytuacji społeczno-politycznej w kraju i przywróceniu zdolności kierowniczych PZPR w państwie, decydujący głos w kwestiach ustroju i funkcjonowania organów wymiaru sprawiedliwości i ochrony prawnej odzyskały organy politycznego nadzoru nad tymi sferami działalności państwa, tj. Wydział Administracyjny oraz Komisja Prawa i Praworządności KC PZPR.

Prace legislacyjne nie ustały, jednak postulaty prokuratorskie i związkowe, zostały politycznie zweryfikowane, a większość z nich odrzucona. 20 czerwca 1985 r. przyjęta została nowa ustawa o Prokuraturze PRL (Dz. U. Nr 31, poz. 138), która nie wprowadziła istotnych zmian w pozycji prokuratury (wciąż podległa Radzie Państwa) i prokuratorów (utrzymanie przepisów o możliwości odwołania z przyczyn „braku rękojmi”, jedynie z umożliwieniem prokura-

58 Zob. Wstępny społeczny projekt nowelizacji kodeksu postępowania karnego (wariant z sędzia śledczym, autorstwa prof. Alfreda Kaftala) [w:] Obywatelskie inicjatywy..., s. 276-293. Zob. też dyskusja prasowa na temat instytucji sędziego śledczego: Co na to nauka? Sędzia śledczy - rozmowa red. J. Klimka z prof. A. Kaftalem, GP 1981, nr 5-6, s. 15; A. Kaftal, Podstawowe problemy nowelizacji kodeksu postępowania karnego, „Palestra” 1981, nr 6, s. 50-57; E. Szwedek, Czy powrót sędziego śledczego?, "Nowe Prawo" (dalej: NP) 1981, nr 6, s. 152-160; Z. Wojtczak, Sędzia śledczy - niewiele to zmieni, GP 1981, nr 12, s. 5; A. Kaftal, Więcej gwarancji w procesie, GP 1981, nr 13-14, s. 4; M. Lipczyńska, Zamiast sędziego śledczego, GP 1981, nr 13-14, s. 4; A. Murzynowski, Problem wprowadzenia instytucji sędziego śledczego, „Państwo i Prawo” 1982, nr 3-4, s. 16-30; M. Jankowski, Sędzia śledczy - wzmocnienie czy osłabienie pozycji sq̨du w procesie karnym?, NP 1982, nr 7-8, s. 133-138. 
torowi złożenia wyjaśnień, i bezwzględnej podległości wobec przełożonych). Rzeczywiste zmiany w ustroju i funkcjonowaniu prokuratury w Polsce przyniósł dopiero przełom lat 1989/9059.

"Solidarność" w środowisku prokuratorskim nie odegrała z kolei większej roli. Jednak podkreślenia wymaga fakt, iż nawet powstanie zaledwie kilku organizacji zakładowych tego związku wywołało ostrą reakcję ze strony kierownictwa prokuratury. Już pod koniec 1980 r., po powstaniu pierwszych kół „Solidarności”, Prokuratura Generalna rozważała potrzebę wprowadzenia prawnego zakazu przynależności pracowników prokuratury do związków zawodowych w przyszłej ustawie o związkach zawodowych lub na mocy specjalnego dekretu lub uchwały Rady Państwa ${ }^{60}$. Zdaniem kierownictwa prokuratury, do czasu prawnego uregulowania tego problemu, należało dążyć „do wyprowadzenia prokuratorów z NSZZ »Solidarność« w drodze przeprowadzenia $\mathrm{z}$ nimi stosownych rozmów partyjnych i służbowych skłaniających do wystąpienia z NSZZ »Solidarność«, a w przypadku odmowy - przez podjęcie decyzji zwolnienia z Prokuratury z powodu braku rękojmi wykonywania funkcji prokuratorskich"61.

Rok przed wprowadzeniem stanu wojennego Prokuratura Generalna rozważała możliwość podjęcia działań kadrowo-represyjnych wobec prokuratorów sympatyzujących z „Solidarnością". Znamienne jest, iż o podjęcie ostatecznej decyzji w tej sprawie kierownictwo prokuratury zwróciło się do sekretarza KC PZPR Kazimierza Barcikowskiego. Odpowiedź Wydziału Administracyjnego KC PZPR w sprawie nie pozostawiała wątpliwości, iż władze partyjne również były za podjęciem stanowczych działań wobec opozycji, jednak sytuacja społeczna uniemożliwiała wdrożenie polityki represyjnej w $1980 \mathrm{r}$. Wydział Administracyjny pisał: „Należy uznać za słuszne stanowisko Prokuratury Generalnej, że pracownicy prokuratury, a w szczególności prokuratorzy, nie powinni należeć do NSZZ »Solidarność«. Należy jednak przewidywać, że podejmowanie działań politycznych, administracyjnych i organizacyjnych, a w szczególności zwalnianie prokuratorów z pracy tylko dlatego, że należą do NSZZ »Solidarność«, niewątpliwie będzie potraktowane przez "Solidarność« jako naruszenie porozumień i statutu, a $\mathrm{w}$ efekcie może doprowadzić do napięcia na linii władza - »Solidarność«"

59 Zob. H. Zięba-Załucka, op. cit., s. 85-96; W. Berutowicz, J. Mokry, Organizacja ochrony prawnej w PRL, Warszawa 1987, s. 228-262.

60 Do wprowadzenia zakazu jednak nie doszło. Nie wprowadzały go również przyjęta w 8 X $1982 \mathrm{r}$. ustawa o związkach zawodowych (Dz. U. Nr 32, poz. 216), ani wspomniana ustawa o Prokuraturze PRL z $1985 \mathrm{r}$.

61 Informacja z dnia 23 XII 1980 r. w sprawie zwiąków zawodowych w Prokuraturze PRL, AAN, 1354 KC PZPR, sygn. LI/39 [brak numeracji porządkowej kart w teczce].

62 Notatka Wydziału Administracyjnego KC PZPR w sprawie związków zawodowych w prokuraturze, ibidem [brak numeracji porządkowej kart w teczce]. 
Po wprowadzeniu stanu wojennego 13 grudnia $1981 \mathrm{r}$. i rozbiciu rewolucyjnego ruchu społecznego, nic nie powstrzymywało już władz przed wdrożeniem planowanych represji wobec niesubordynowanych politycznie prokuratorów. Kierownictwo prokuratury przeprowadziło rozmowy dyscyplinujące, które objęły w szczególności prokuratorów związanych z "Solidarnością". W efekcie przeprowadzonej politycznej weryfikacji kadrowej zwolniono 26 prokuratorów, w tym 15 członków NSZZ „Solidarność”63. Sięgnięto wówczas po krytykowany przez środowisko przepis art. 13 ustawy o Prokuraturze PRL umożliwiający pozbawianie prokuratorów stanowisk z przyczyn braku rękojmi należytego wykonywania obowiązków.

\section{Bibliografia}

Berutowicz W., Mokry J., Organizacja ochrony prawnej w PRL, Warszawa 1987.

Biernacki L., Kronika „Solidarności”. 20 lat dzień za dniem..., Sopot 2000.

Chcemy współdecydować o wszystkim - rozmowa z przedstawicielami RN ZZPP, „Gazeta Prawnicza" 1981, nr 10.

Co na to nauka? Sędzia śledczy - rozmowa red. J. Klimka z prof. A. Kaftalem, „Gazeta Prawnicza" 1981, nr 5-6.

Eksner J., Prokurator rzecznikiem praworządności, Warszawa 1974.

Friszke A., Rewolucja Solidarności 1980-1981, Kraków 2014.

Giełżyński W., Stefański L., Gdańsk, sierpień 80, Warszawa 1981.

63 Z informacji Wydziału Administracyjnego KC PZPR wynika, iż z urzędu zwolniono 6 wiceprokuratorów prokuratur rejonowych: Stanisława Domaradzkiego z Sanoka, Janusza Nogackiego z Cieszyna, Jana Arciszewskiego z Warszawy, Leszka Lackorzyńskiego z Gdańska, Aleksandra Herzoga z Krakowa, Stefana Śnieżko z Olsztyna (dodatkowo internowanego) oraz jednego podprokuratora Prokuratury Rejonowej w Bielsku Białej Mariana Młynarskiego. Ponadto po przeprowadzonej weryfikacji, na własną prośbę, z prokuratury odeszli: wiceprokurator Prokuratury Wojewódzkiej w Gdańsku Andrzej Studziński; dwaj podprokuratorzy prokuratur wojewódzkich: Lech Toporek z Gdańska i Ryszard Wojcieszak ze Szczecina; dwaj wiceprokuratorzy prokuratur wojewódzkich: Jacek Szafnicki ze Skierniewic i Edward Kisielewski z Opola; trzej wiceprokuratorzy prokuratur rejonowych: Krzysztof Bachmiński z Krakowa, Janina Jurewicz i Danuta Profaska z Olsztyna; ośmiu podprokuratorów prokuratur rejonowych: Andrzej Podstawski z Krosna, Danuta Woch z Pszasnysza, Hanna Linettej-Thrun z Gdańska oraz Kazimierz Maczewski, Grzegorz Jankowski, Michał Sklepik, Marcin Sobecki i Maria Trędowicz - wszyscy ze Szczecina; jeden asesor Prokuratury Rejonowej w Stargardzie Szczecińskim Tomasz Hofman; dwaj aplikanci z Prokuratury Wojewódzkiej w Szczecinie Jerzy Pająk i Henryk Kozłowski. Zob. Notatka dot. decyzji kadrowych w sadownictwie i prokuraturze z 28 II 1982 r., AAN, 1354 KC PZPR, LI/39 [brak numeracji porządkowej kart $\mathrm{w}$ teczce]. Zob. też Prawa czlowieka $i$ obywatela $w$ PRL (13.XII.1981 r. - 31.XII.1982 r.), oprac. Zespół Redakcyjny Komitetu Helsińskiego z up. Z. Bujaka, B. Lisa, W. Hardka, J. Piniora, E. Szumiejki, Paryż 1983, s. 63-64. 
Herzog A., Z dziejów społecznego projektu ustawy o prokuraturze, [w:] Obywatelskie Inicjatywy Ustawodawcze Solidarności 1980-1990, oprac. Barczyk K., Grodziski S., Grzybowski S., Warszawa 2001.

Holzer J., "Solidarność” 1980-1981. Geneza i historia, Paryż 1984.

Jankowski M., Sędzia śledczy - wzmocnienie czy osłabienie pozycji sądu w procesie karnym?, „Nowe Prawo” 1982, nr 7-8.

Kaftal A., Podstawowe problemy nowelizacji kodeksu postępowania karnego, „Palestra” 1981, nr 6.

Kaftal A., Więcej gwarancji w procesie, „Gazeta Prawnicza” 1981, nr 13-14.

Lipczyńska M., Zamiast sędziego śledczego, „Gazeta Prawnicza” 1981, nr 13-14.

Mniej lub więcej solidarnie - relacja Piotra Ambroziewicza z przebiegu konferencji w Sądzie Wojewódzkim w Poznaniu w dniach 27-28 X 1980 r., „Prawo i Życie" 1980, nr 46.

Murzynowski A., Problem wprowadzenia instytucji sędziego śledczego, „Państwo i Prawo" 1982, nr 3-4.

Niewiński K., PZPR a sądownictwo w latach 1980-1985. Próby powstrzymania "solidarnościowej" rewolucji, Oświęcim 2016.

Niewiński K., PZPR a związki zawodowe w sądownictwie po sierpniu 1980 r., "Z Dziejów Prawa" 2015, t. 8 (16).

Obywatelskie Inicjatywy Ustawodawcze Solidarności 1980-1990, oprac. Barczyk K., Grodziski S., Grzybowski S., Warszawa 2001.

Osiński K., Rybarczyk P., Kryzys bydgoski 1981. Przyczyny, przebieg, konsekwencje, t. I, Bydgoszcz-Gdańsk-Warszawa 2013.

Osiński K., Rybarczyk P., Kryzys bydgoski 1981. Przyczyny, przebieg, konsekwencje, t. II, Bydgoszcz-Gdańsk-Warszawa 2013.

Paczkowski A., Pół wieku dziejów Polski, Warszawa 2007.

Potrzeba prawa - rozmowa red. J. Waniorka z przedstawicielami kierownictwa ZZPP, „Prawo i Życie” 1981, nr 32.

Prawa człowieka i obywatela w PRL (13.XII.1981 r. - $31 . X I I .1982$ r.), oprac. Zespół Redakcyjny Komitetu Helsińskiego z up. Z. Bujaka, B. Lisa, W. Hardka, J. Piniora, E. Szumiejki, Paryż 1983.

Sielezin J. R., Koncepcje i spory programowe opozycji politycznej w Polsce w latach 1976-1982, Wrocław 2012.

Sowa A.L., Historia polityczna Polski 1944-1991, Kraków 2011.

Sowa A.L., Wielka historia Polski, od drugiej do trzeciej Rzeczypospolitej (1945-2001), t. 10, Kraków 2001.

Szczęsny J., Obywatelskie Inicjatywy Ustawodawcze, „Gazeta Prawnicza” 1981, nr 13-14 .

Szwedek E., Czy powrót sędziego śledczego?, „Nowe Prawo” 1981, nr 6.

Uchwała I Krajowego Zjazdu Związu Zawodowego Pracowników Prokuratury PRL, „Gazeta Prawnicza" 1981, nr 9. 
Walczak R., Polityka, sady, prokuratura, Warszawa 1990.

Włodyka S., Ustrój organów ochrony prawnej, Warszawa 1968.

Wojtczak Z., Sędzia śledczy - niewiele to zmieni, „Gazeta Prawnicza” 1981, nr 12. Zięba-Załucka H., Instytucja prokuratury w Polsce, Warszawa 2003. 